\title{
The Utility of Acid Phosphatase as a Marker in Malaria
}

\author{
Dr. Jyoti Prakash Yogi ${ }^{1}$, Dr. Mukesh Soni ${ }^{2}$, Dr. D. Devpura ${ }^{3}$ \\ ${ }^{1}$ Residents, Department of Gen Medicine SMS Medical College/ RUHS, RAJ., India \\ ${ }^{2}$ Residents, Department of Gen Medicine SMS Medical College/ RUHS, RAJ., India \\ ${ }^{3}$ Sen. Prof. \& Unit Head, Department of Gen Medicine SMS Medical College/ RUHS, RAJ., India
}

\begin{abstract}
Invasion of the human erythrocytes by the malarial parasite brings about considerable metabolic changes in the host cell. In this study we compared acid phosphatase (ACP) levels in 45 cases of malaria with 45 cases of non-malarial fever and 45 normal individuals. In our study the serum ACP levels are highly increased in malaria patients when compared to non-malarial fever patients and it was highly significant (p<.001). The serum ACP levels are significantly increased in PF and Mixed groups compared to PV group. The level of $\mathrm{Hb}$ was decreased in all malaria patients, thisindicate that malarial parasite uses host erythrocytes $\mathrm{Hb}$ as major nutrient source. There is negative correlation between ACP and Hb in malaria patients(r= -0.924) which is statistically highly significant. Increase in serum ACP levels in malaria patients may be used as an additional investigation in the diagnosis of malaria.
\end{abstract}

Keywords: Acid Phosphatase, Hemoglobin, Malaria

\section{Introduction}

Malaria occurs throughout most of the tropical regions of the world. Even a century after the discovery of malaria transmission through mosquitoes in India by Sir Ronald Ross in 1897, malaria continues to be one of India's leading public health problems. Malaria is caused by infection with protozoan parasites belonging to the genus Plasmodium transmitted by female Anopheles species mosquitoes. Four species of genus Plasmodium infect humans: Plasmodium falciparum, P. vivax, P. ovale and P. malariae ${ }^{(1,2)}$.

The pathogen passes 3 phases during its development-

- Asexual phase forming sporozoites in female Anopheles mosquito

- Multiplication of sporozoites in human liver cell (preerythrocytic phase) \&

- Erythrocytic phase whereby merozoites originating from liver cells develop in schizonts ${ }^{(1,2)}$.

The invasion of human erythrocytes by the malarial parasite is during the phase of erythrocytic schizogony. The alterations in the major antioxidants of the erythrocytes $\&$ the peroxide lysis of the erythrocytes may result inrelease of enzymes like ACP.

This may be due to hemolysis caused by host-parasite interactions and increased oxidative stress ${ }^{(1-4)}$.

Acid phosphatase (ACP) in serum has normal value $<5.5 \mathrm{IU} / \mathrm{ml}$ but is increased in various conditions like prostate diseases (prostate cancer, BPH), breast cancer, bone diseases (Paget's disease, bone cancer), multiple myeloma \&myeloproliferative disorders, Gaucher's disease, liver diseases, chronic renal failure etc. ${ }^{(5,6,7)}$

Erythrocytic acid phosphatase (ACP1:EC3.1.3.2) shows an electrophoretic polymorphism determined by 3 common alleles $(\mathrm{Pa}, \mathrm{Pb}$ and $\mathrm{Pc})$ at an autosomal locus. ACP activity can be measured by using substrates either thymophthalein phosphate \& beta-glycerophosphate(both are specific for prostatic iso-enzyme) or p-nitrophenylphosphate. Addition of tartrate selectively inhibits prostatic isoenzyme. Most of the acid phosphatase activity of normal sera \& of patients with metastasizing prostatic carcinoma is inhibited by incubation in the presence of M/200 NaF. Erythrocytic acid phosphatase, however, is not significantly inhibited ${ }^{(8-13)}$. Increase in serum ACP levels in malaria patients could serve as a marker for hemolysis indicating the active stage of the disease, which may be used as additional investigation in the diagnosis of malaria ${ }^{(14)}$.

\section{Literature Survey}

BenedictaD'Souza conducted a study is to evaluate the levels of acid phosphatase in malaria and to check its possible use as a marker enzyme in its detection and prognosis in 62 subjects out of which 25 were malaria patients (14).In thisstudy we compared acid phosphatase (ACP) levels in 45 cases of malaria with 45 cases of non malarial fever and 45normal individuals from May 2012 to April 2013.

\section{Material and Method}

This hospital based comparative analytical study was conducted among 45 patients with fever who were slide positive for malaria and 45 patients with fever who were slide negative for malaria admitted to SMS hospital and 45 healthy attendants of patients during May 2012 to April 2013. Of 45 malarial patients 16 had P. Falciparum malaria, 24 patients had P.vivax malaria and 5 patients had mixed malaria that is having both P. Falciparum and P. vivax malaria.

A finger prick sample was taken to prepare thick and thin blood films to determine the presence or absence of the malarial parasite. Those showing slide positive were 


\section{International Journal of Science and Research (IJSR) \\ ISSN (Online): 2319-7064 \\ Index Copernicus Value (2015): 78.96 | Impact Factor (2015): 6.391}

considered as malarial fever and those with slide negative for malaria were considered as non-malarial fever group. Both groups were screened for the level of acid phosphatase in their blood sample. $5 \mathrm{ml}$ of venous blood was collected randomly in EDTA bottles from malaria patients, nonmalarial fever patients and normal healthy subjects. It was centrifuged for $10 \mathrm{~min}$. The plasma was collected taking care to avoid hemolysis and was used for the estimation of the ACP level. Estimation of ACP was done by kit method using acid phosphatase reagent set. The $\alpha$-naphthol released from the substrate $\alpha$-naphthol phosphate by acid phosphatase is coupled with fast red TR to produce a colored complex which absorbs light at $405 \mathrm{~nm}$. The reaction can be quantified photometrically because the coupling reaction is instantaneous. L-tartrate inhibits prostatic acid phosphatase but does not interfere with the reaction mechanism.

The hemoglobin $(\mathrm{Hb})$ content of erythrocytes was determined by the Cyanmethaemoglobin method [13].The statistical analysis was done using the Mann- Whitney's U test. P-value $<0.05$ is considered to be significant. Correlations between theparameters were estimated by spearman's rank correlations.

\section{Results and Discussions}

Table 1: Serum levels of ACP (in IU/ml ) in malaria patients, non-malarial fever patients and control subjects

\begin{tabular}{|c|c|c|c|c|c|}
\hline & Control (45) & $\begin{array}{c}\text { Non-malarial } \\
(45)\end{array}$ & PV (24) & PF (16) & Mixed (5) \\
\hline ACP & $2.3 \pm 0.43$ & $3.35 \pm 0.22$ & $6.0 \pm 0.50$ & $6.61 \pm 0.22$ & $7.78 \pm .017$ \\
\hline
\end{tabular}

The serum ACP levels are highly increased in malaria patients when compared to non-malarial fever patients and it was highly significant $(\mathrm{p}<.001)$. The serum ACP levels are highly increased in PF and Mixed groups compared to PV group and it was highly significant $(\mathrm{p}<.001)$. The serum ACP levels are highly increased in malaria patients when compared to the controls and it was also highly significant $(\mathrm{p}<.001)$. Mean acid phosphatase value in males and females was $3.97 \pm 1.76$ and $4.1 \pm 1.92 \mathrm{IU} / \mathrm{ml}$ respectively it was statistically not significant ( $\mathrm{p}>.05)$.

Table 2: Serum levels of $\mathrm{Hb}(\mathrm{in} \mathrm{g} / \mathrm{dl})$ in malaria patients, non-malarial fever patients and control subjects

\begin{tabular}{|c|c|c|c|c|c|}
\hline & $\begin{array}{c}\text { Control } \\
(45)\end{array}$ & $\begin{array}{c}\text { Non-malarial } \\
(45)\end{array}$ & PV (24) & PF (16) & Mixed (5) \\
\hline $\mathrm{Hb}$ & $12.63 \pm 0.74$ & $11.27 \pm 0.40$ & $10.6 \pm 0.50$ & $10.18 \pm 0.22$ & $10.1 \pm 0.15$ \\
\hline
\end{tabular}

The $\mathrm{Hb}$ content is significantly decreased in malaria patients compared to the non-malarial fever group $(\mathrm{P}<0.001)$ and compared to the control subjects $(\mathrm{P}<0.001)$.

Table 3: Correlation between ACP \& $\mathrm{Hb}$

\begin{tabular}{|l|l|l|}
\hline Group & & Hb \\
\hline PV ACP & Correlation Coefficient & $-1.000^{* *}$ \\
\cline { 2 - 3 } & Sig. (2-tailed) & .000 \\
\cline { 2 - 3 } & $\mathrm{N}$ & 24 \\
\hline \multirow{3}{*}{ PF ACP } & Correlation Coefficient & $-1.000^{* *}$ \\
\cline { 2 - 3 } & Sig. (2-tailed) & .000 \\
\cline { 2 - 3 } & $\mathrm{N}$ & 16 \\
\hline Mixed ACP & Correlation Coefficient & $-.975^{* *}$ \\
\cline { 2 - 3 } & Sig. (2-tailed) & .005 \\
\hline
\end{tabular}

\begin{tabular}{|l|l|l|}
\hline & $\mathrm{N}$ & 5 \\
\hline \multirow{5}{*}{ Total ACP } & Correlation Coefficient & $-.924^{* *}$ \\
\cline { 2 - 3 } & Sig. (2-tailed) & .000 \\
\cline { 2 - 3 } & $\mathrm{N}$ & 45 \\
\hline \multirow{3}{*}{$\begin{array}{l}\text { ACP } \\
\text { Conmalarial }\end{array}$} & Correlation Coefficient & -.119 \\
\cline { 2 - 3 } & Sig. (2-tailed) & .436 \\
\cline { 2 - 3 } & $\mathrm{N}$ & 45 \\
\hline \multirow{2}{*}{ Control ACP } & Correlation Coefficient & -.260 \\
\cline { 2 - 3 } & Sig. (2-tailed) & .084 \\
\cline { 2 - 3 } & $\mathrm{N}$ & 45 \\
\hline \multirow{2}{*}{ Correlation is significant at the 0.01 level (2-tailed). }
\end{tabular}

Correlations between the values were estimated by spearmann's Correlation co-efficient.

There is negative correlation between $\mathrm{ACP}$ and $\mathrm{Hb}$ in malaria patients $(r=-0.924)$ which is statistically highly significant $(\mathrm{P}<0.001)$.

\section{Conclusion}

In our study there is a significant increase in serum ACP levels in malaria patients. Thus Increase in serum ACP levels in malaria patients may be used as an additional investigation in the diagnosis of malaria.

\section{Future Scope}

Our study has some limitations also. Because of small sample size sensitivity and specificity of acid phosphatase as a diagnostic test of malaria could not be determined. There is need for further study to use this enzyme as a diagnostic and prognostic marker in malaria in addition to other routine tests involved.

\section{References}

[1] Malaria In:Park's Text book of preventive \& social MedicineEd K Park, $19^{\text {th }}$ edn.2007;201-19.

[2] Paniker CKJ. Malaria parasites. In: Textbook of medical parasitology. $6^{\text {th }}$ Ed. New Delhi: Jayapee Brothers Medical Publishers; 2007. p. 65-95.

[3] Anderson HR, Nielsen JB, Nielsen F, Philippe G Antioxidative enzyme activities in human erythrocytes. Clin Chem. 1997; 43(4): 562-8.

[4] Goldberg DE, Slater AF, Cerani A, Henderson GB. Hemoglobin degradation in malaria parasite Plasmodium falciparum:an ordered process in a unique organelle. ProcNatlAcad Sci. 1990; 87(8):2931-5.

[5] Shinowara, G. Y., Jones, R. M., and Reinhart, H.: The estimation of serum inorganic phosphate and "acid" and "alkaline" phosphatase activity. J. Biol. Chem., 1942, 149, 921.

[6] Gutman EB, Gutman AB: Estimation of acid phosphatase activity ofblood serum. J BioiChem 136:201,1940.

[7] Andersch MA, Szczypinski AJ: Use of pnitrophenyl phosphate substrate in determination of serum acid phosphatase. Am J Clin PathoI17:571, 1947

[8] Jacobsson K: The determination of tartrate-inhibited phosphatase in serum. ScandJClin Lab Invest 12:367, 1960 


\section{International Journal of Science and Research (IJSR) \\ ISSN (Online): 2319-7064}

Index Copernicus Value (2015): 78.96 | Impact Factor (2015): 6.391

[9] Ozar MB, Isaac CA, Valk WL: Methods for the elimination of errors in serum acid phosphatase determinations. J UroI74:150, 1955

[10] Gutman, A. B.andGutman, E. B. "Acid"phosphatase activity of the serum of normal human subjects. Proc. Hoc. Exp. Biol. Med. S8:470-78, 1938.

[11] Gutman, E. B. and Gutman, A. B. Erythrocyte phosphatase activity in hemolysed sera and estimation of serum "acid" phosphatases, Proc. Soc. Exp. Biol. Med. 47:513-15, 1941.

[12] Dissing J. Immunochemical characterization of human red cell acid phosphatase isoenzymes. Biochem Genet. 1987;25:11-2.

[13] Varley H. Practical Clinical Biochemistry.5th ed. In: Determination of serum acid phosphatase. London: William Heinemann Medical Books Ltd; 1980. p 913915.

[14]Benedicta D'Souza • Rajeevalochana Parthasarathy• Sreekantha Vivian D'Souza. Acid Phosphatase as a Marker in Malaria.Ind J ClinBiochem (Oct-Dec 2011) 26(4):396-399

\section{Author Profile}

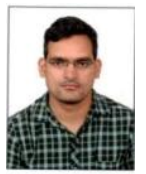

Dr. J. P. Yogi received the graduation and post graduation degree in general medicine from SMS Medical college jaipur Rajasthan in 2011 and 2014 respectively. During 2011-2014 he stayed in SMS Medical College circumference.

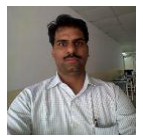

Dr. Mukesh Soni received the graduation and post graduation degree in general medicine from SMS Medical college jaipur Rajasthan in 2011 and 2014 respectively. During 2011-2014 he stayed in SMS Medical College circumference.

Dr. D. Devpura was worked as a Sen. Prof. \& Unit Head, Department of Gen Medicine SMS Medical College RUHS, RAJ., INDIA . 